\title{
Possible effects of nest predation on the breeding success of Ferruginous Ducks Aythya
} nyroca

\author{
JENŐ J. PURGER and LÍDIA A. MÉSZÁROS
}

\section{Summary}

To investigate whether nest predation can influence the breeding success of Ferruginous Ducks Aythya nyroca, artificial nests were used in Nagyberek, the strictly protected swamp pond of the Juniper Woodland Nature Conservation Area (Somogy county, south Hungary). Experimentation lasted for 4 weeks, a similar length of time to the incubation period of Ferruginous Ducks. After I week, 80\% of nests were intact, after 2 weeks only $46 \%$, and after 3 and 4 weeks only $2 \%$ remained undamaged. Nest survival rates were not affected by the width of the sedge stands, but as water levels surrounding nests decreased, nests became more accessible to Wild Boar Sus scrofa and other land mammal predators, which increased the rate of predation. Artificially maintaining water levels would not only decrease the predation rate of nests, but would also maintain feeding areas for ducks. Wild Boar were the main cause of clutch loss in this area, and therefore by management measures, such as a reduction in their abundance or attracting them away from potential nesting sites by providing food elsewhere, the breeding success of the Ferruginous Ducks may be further improved.

\section{Introduction}

The breeding range of the Ferruginous Duck Aythya nyroca comprises the steppe, desert and forest zones of Eurasia, extending from the Mediterranean basin to central China (Cramp and Simmons 1977). Southern breeding areas overlap with the winter ranges, which extend east from West Africa to South-East Asia and north from subSaharan Africa to southern Europe (Robinson and Hughes 2003). Ferruginous Duck is listed as Near Threatened and has undergone a long-term, but recently massive, population decline (Krivenko et al. 1994). In the European part of the breeding area the population is estimated at $11,000-25,000$ pairs (Krivenko et al. 1994). The population breeding in Hungary in the late 1980 s was estimated at around 1,200-1,600 pairs (Krivenko et al. 1994), and at 500-600 pairs in the late 1990s (Magyar et al. 1998). This population decline is the result of habitat destruction, wetland drainage, intensive hunting, fishpond management, and predatory fish taking ducklings (Krivenko et al. 1994, Petkov et al. 2003). The effect of nest predation on breeding success is believed to be unimportant in this decline, although breeding success is one of the most significant factors influencing the overall abundance of duck populations (Klett et al. 1988, Greenwood et al. 1995). Nest predation is influenced by a number of factors, such as human disturbance (Hammond and Forward 1956, Vacca and Handel 1988), nest density, vegetation structure and density (Clark and Nudds 1991), habitat edge 
(Yahner and Wright 1985, Batáry and Báldi 2004), nest concealment (Martin 1995), water depth, and the degree of nest inaccessibility (Brua 1999).

Experimental nest predation studies have greatly contributed to the understanding of both breeding success and nest predation (Paton 1994, Major and Kendal 1996, Söderström et al. 1998, Báldi 1999). With the use of artificial nests and dummy eggs, information can be gathered about the extent of nest predation experienced by wild duck species, without any disturbance to natural nests. Using this method, it is also possible to identify the major predators (e.g. large and small mammals, birds).

Using artificial nests and eggs, the aim of our study was to investigate to what extent the breeding success of Ferruginous Ducks might be influenced by nest predation. Answers were sought to the following questions: (I) How does the survival of clutches change through the incubation period? (2) Does the cover of vegetation containing the nests influence breeding success? (3) What are the principal predators of duck eggs?

\section{Study area}

The highest numbers of Ferruginous Ducks in the South-Transdanubian region of Hungary breed in the Barcs Juniper Woodland and in Lake Baláta (Kárpáti 1979). The Barcs Juniper Woodland Nature Conservation Area (Somogy county) has been part of the Danube-Drava National Park since 1996. It covers 3,520 ha, and the altitude varies between 100 and $150 \mathrm{~m}$ a.s.l. Its climate is influenced by sub-Mediterranean and subAtlantic effects. Annual precipitation is approximately $800 \mathrm{~mm}$. In the conservation area there are many small swamp ponds $(30-40)$ fed by precipitation that dry out periodically every year. The largest pond is the strictly protected Nagyberek, which can cover 100 ha in the spring. Its water depth can be $1.5-1.7 \mathrm{~m}$. During periods of little rain its area can shrink to $20-40$ ha. In the shallow parts there are stands of Tufted Sedge Carex elata, and around the lake there are Common Alder Alnus glutinosa groves. The existence and condition of this vegetation depends primarily on water supply and groundwater level (Juhász et al. 1985, Juhász 1997).

In the first days of June 1974, Kárpáti (1979) found nine Ferruginous Duck nests in Nagyberek, and together with pairs breeding on nearby fishponds the population grew by midsummer to 100-120 pairs. Marián and Puskás (1985) established that Ferruginous Ducks nest in habitats similar to those used by Mallards Anas platyrhynchos, although fewer in number. As reported by Fenyő Si (1993), their population is decreasing, the number of nesting pairs having stayed below to pairs between 1983 and 1993 .

\section{Methods}

Because the area was typical Ferruginous Duck habitat (Kárpáti 1979), it seemed suitable for a nest predation study. Fifty artificial nests were positioned $20 \mathrm{~m}$ apart (Bayne and Hobson 1999, Báldi 1999), each inside a tuft of sedge, and were sited in such a way as to imitate natural nests as closely as possible (Guyn and Clark 1997). The width of the sedge stand ranged from 1 to $5 \mathrm{~m}$ on the western side of the lake and from to 25 to $35 \mathrm{~m}$ on the eastern side. Twenty-five artificial nests were placed in the narrow sedge strip (about 1-4 m from the lakeside), and 25 in the broad sedge stand (about 5-20 $\mathrm{m}$ from the lakeside). 
In Hungary, the clutch of Ferruginous Ducks is complete around May-June (Magyar et al. 1998). On 26 May 2003, four chicken eggs and a similar-sized Plasticine egg were placed into each of the nests. The dummy eggs contained a $2-3 \mathrm{~cm}$ stick onto which a $1.5 \mathrm{~m}$ long thread was attached and its free end tied to the sedge leaves. This was necessary to prevent the egg from being removed from the nest by the predator. Both Plasticine and chicken eggs were stored outdoors for 1 week before the start of the experiment (Báldi 1999). A $1 \mathrm{~cm}$ wide, $20 \mathrm{~cm}$ long pale orange tape was used for marking the place of each nest (Esler and Grand 1993, Maxson and Riggs 1996, Butler and Rotella 1998), which was tied to a lakeside tree near the nest. On the day the artificial nests and eggs were put out, the sedge tufts holding them stood in $60-80 \mathrm{~cm}$ of water.

The nests were checked on days I (27 May), 2 (28 May), 4 (3o May), 7 (2 June), 14 (9 June), 21 ( 16 June) and 28 (23 June) after being installed, at between 12 hoo and 15hoo. To avoid creating tracks, we always approached them from a different direction (Clark and Wobeser 1997). Also, care was taken not to make any change to the nests during each check (Brua 1999). During the last check, the remaining eggs and marking tapes were collected. A nest was considered to have been predated when at least one egg was damaged or missing (Clark and Wobeser 1997, Olson and Rohwer 1998, Báldi 1999).

During the study the following potential nest predators were observed: Hooded Crow Corvus corone cornix, Raven Corvus corax and Marsh Harrier Circus aeruginosus. Furthermore the presence of Otter Lutra lutra, Red Fox Vulpes vulpes, Badger Meles meles, Pine Marten Martes martes, Wild Boar Sus scrofa and Northern Water Vole Arvicola terrestris was proved from tracks and droppings. The identification of predators visiting nests was based on changes to the nests, such as tooth-marks left on Plasticine eggs, and droppings (e.g. Red Fox, Otter, Pine Marten) or footprints (Badger, Wild Boar) found around the nests.

The Mayfield nest survival method was used (Mayfield 1975) and in the statistical analysis a G-test was used for goodness of fit for two categories, and when $\mathrm{df}=1$, Yates' correction for continuity was applied (Zar 1999). A minimum probability level of $P<0.05$ was accepted for all the statistics.

\section{Results}

The study area was surveyed several times during April 2003, but only 1 or 2 pairs of Ferruginous Duck and 2 or 3 pairs of Mallard were seen, which is fewer than in previous years. On the first day after placing the artificial nests all of them were intact. By the second day, predators had discovered one; by the fourth day they found two nests. After 1 week, $80 \%$ of nests were intact, after 2 weeks only $46 \%$, and after 3 weeks only $2 \%$ (one nest) remained undamaged. After 4 weeks the situation was the same (Figure 1 ).

The survival chances of nests were similar in the western, narrow section of the lake and the eastern, broad sedge stand, in both the first $\left(G_{c}=1.23, \mathrm{df}=1, \mathrm{NS}\right)$ and second $\left(G_{c}=0.81, \mathrm{df}=1, \mathrm{NS}\right)$ weeks after they had been installed. After the third week only one nest was left undisturbed at the eastern side of the lake, and this remained intact even at the end of the fourth week, when the sedge tuft holding the nest had been completely out of the water for more than 10 days. 


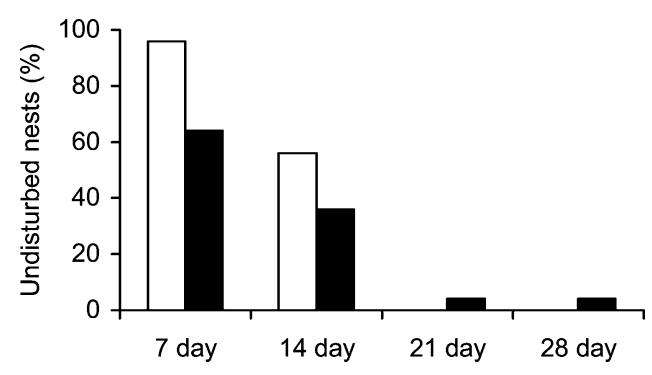

Figure 1. Percentage of undisturbed nests during the 4 weeks after they had been installed. White bars, narrow vegetation strip; black bars, broad vegetation strip.

During the first week, most nests were predated by birds, as shown by single chicken eggs removed or broken open. The other eggs were also removed from the nests or damaged within a couple of days. Later on, whole clutches were damaged at once, and this presumably indicates a mammalian predator (Figure 2). Sixty-two per cent of Plasticine eggs were left in the nests, but only $44 \%$ could be evaluated because 6 were intact and another 3 had unidentifiable tooth-marks. The remaining 22 Plasticine eggs had tooth-marks left by Wild Boar (59\%), Red Fox (14\%), Pine Marten (9\%), Otter (9\%), Badger (4.5\%) and Northern Water Vole (4.5\%).

\section{Discussion}

If the whole Ferruginous Duck incubation period is considered (28 days), and the chances of a nest surviving are assumed to be similar to that of artificial nests, it can be stated that during the incubation period $98 \%$ of nests are discovered by predators. A number of differences between artificial and natural nests mean that the results of this study may not provide an unbiased estimate of predation rates in natural Ferruginous Duck nests. Artificial nests are not covered or camouflaged by an incubating bird, and therefore are more easily discovered by bird predators (Butler and Rotella 1998). In the first days predation was low, suggesting that the nests created in the sedge tufts were appropriately concealed. The importance of nest concealment is dependent on the makeup of the local predator community (Clark and Nudds 1991). Nest concealment typically is of little importance to nest success in habitats where mammalian predators predominate over avian predators (Maxson and Riggs 1996).

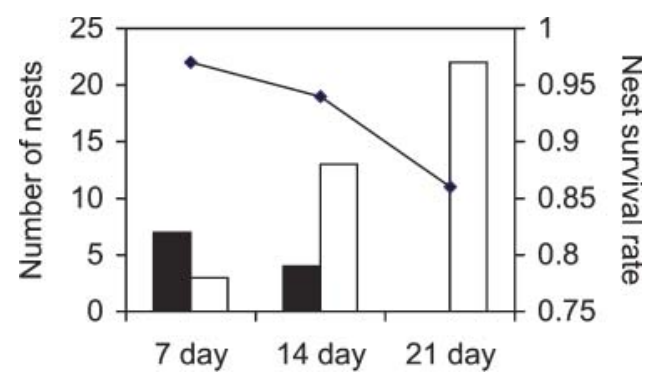

Figure 2. Nest survival rates, and number of nests damaged during the first, second and third weeks by birds (black bars) and mammals (white bars). 
However, natural nests may be more vulnerable to mammalian predators, which may rely more heavily on olfactory cues (Guyn and Clark 1997). Another difference between artificial and natural nests is that there are no parent birds present at artificial nests. Parent birds may defend their nests from predators (MacIvor et al. 1990) or may attract the attention of predators by their movements, smell or sound at the nest (Matthews et al. 1999).

According to Butler and Rotella (1998), breeding success in artificial and natural duck nests did not differ, although the survival of artificial nests can be higher than that of natural ones (Clark and Wobeser 1997, Guyn and Clark 1997, respectively). There were only two Ferruginous Duck nests (both damaged) found in the study area, so the survival chances of the two nest types could not be compared.

It is likely that high, but similar predation in the narrow and broad sedge strips resulted from their marginal location. Krasowski and Nudds (1986) assumed that nests located in strips or narrows fringes of natural habitat may be less successful than those in larger blocks of cover. Nest habitat variables did not influence the probability of nest failure or predation on over-water duck nests (Krasowski and Nudds 1986, Maxson and Riggs 1996).

Our findings support those revealed by Opermanis et al. (2001), i.e. that avian predators active at the beginning of the breeding season are gradually replaced by more effective mammalian predators. The composition of nest predators changed primarily because of the decreasing water level. During the first week, every sedge tuft holding a nest was still in water $50-60 \mathrm{~cm}$ deep. By the second week the water level had decreased to $25-30 \mathrm{~cm}$, and by the end of the third week nearly all the sedge tufts were out of the water. As the water level dropped, nests became more accessible to Wild Boars searching for food at the side of the lake. Thus, the survival chances of nests decreased dramatically week by week. Predation pressures on females and nests differ between dry and over-water habitats because water is often a barrier to many mammalian predators (Sargeant and Arnold 1984). Water depth has not been associated with nesting success for natural nests of diving ducks (Krasowski and Nudds 1986, Maxson and Riggs 1996, Brua 1999); however, as water level decreases, disturbance and predation pressure can intensify (Wieloch 2002). Maintaining water at a constant level may be essential not only for successful breeding, but for feeding also. Ferruginous Ducks feed at depth, chiefly by diving (Green 1998); therefore a dramatic drop in water level threatens the size of feeding area, and may affect the duck's mode of feeding.

Some predators feed on duck eggs early in the season and later switch to alternative prey (Crabtree and Wolfe 1988). Therefore, late nests may, in general, be less vulnerable to predation (Beauchamp et al. 1996). Nest success depends not only on predator abundance and location, but also on predator behaviour and, specifically, how predators forage and what they eat (Ackerman 2002). Nest success of ducks may be positively correlated with the abundance of small mammals (Byers 1974, Weller 1979) or the wide availability of insects (Crabtree and Wolfe 1988), which may be alternative prey for nest predators. When dry conditions result in lower productivity of primary producers, alternative prey may become scarce and predators may consume a higher proportion of duck eggs (Johnson et al. 1989). If there is sufficient food available for predators (e.g. if they are offered supplementary food), they damage fewer nests (Greenwood et al. 1998). 
Wild Boar are the main cause of nest loss (and perhaps this would also be true for real nests) and there could be two options to deter them: (I) keep the water levels higher (which the ducks may need for feeding) and (2) provide supplementary feed for the boars.

\section{Acknowledgements}

The authors would like to thank Mr József Stix and Mr Ákos Zöldvári, rangers in Danube-Drava National Park, for their field assistance, and Mr László Fenyô Si and Mr Zoltán Horváth for sharing with us their professional experience. We have received useful comments on the manuscript from Dr András Báldi, Dr Martin Jones, Mr Balázs Trócsányi and two anonymous referees.

\section{References}

Ackerman, J. T. (2002) Of mice and mallards: positive indirect effects of coexisting prey on waterfowl nest success. Oikos 99: 469-480.

Báldi, A. (1999) The use of artificial nests for estimating rates of nest survival. Ornis Hung. 8-9: 39-55. (In Hungarian with English summary.)

Batáry, P. and Báldi, A. (2004) Evidence of an edge effect on avian nest success. Conserv. Biol. 18: 389-400.

Bayne, E. M. and Hobson, K. A. (1999) Do clay eggs attract predators to artificial nests? J. Field Ornithol. 70: 1-7.

Beauchamp, W. D., Koford, R. R., Nudds, T. D., Clark, R. G. and Johnson, D. H. (1996) Longterm declines in nest success of prairie ducks. J. Wildl. Manage. 6o: 247-257.

Brua, R. B. (1999) Ruddy Duck nesting success: do nest characteristics deter nest predation? Condor 101: 867-870.

Butler, M. A. and Rotella, J. J. (1998) Validity of using artificial nests to assess duck-nest success. J. Wildl. Manage. 62: 163-171.

Byers, S. M. (1974) Predator-prey relationship on an Iowa waterfowl nesting area. Trans. North Am. Wildl. Nat. Resour. Conf. 39: 223-229.

Clark, R. G. and Nudds, T. D. (1991) Habitat patch size and duck nesting success: the crucial experiments have not been performed. Wildl. Soc. Bull. 19: 534-543.

Clark, R. G. and Wobeser, B. K. (1997) Making sense of scents: effects of odour on survival of simulated duck nests. J. Avian Biol. 28: 31-37.

Crabtree, R. L. and Wolfe, M. L. (1988) Effects of alternate prey on skunk predation of waterfowl nests. Wildl. Soc. Bull. 16: 163-169.

Cramp, S. and Simmons, K. E. L., eds. (1977) The birds of the western Palearctic, 1. Oxford: Oxford University Press.

Esler, D. and Grand, J. B. (1993) Factors influencing depredation of artificial duck nests. J. Wildl. Manage. 57: 244-248.

Fenyô Si, L. (1993) Birds in the Barcs Landscape Protection Area (1983-1993). Allattani Közlemények 79: 55-66. (In Hungarian with English summary.)

Green, A. J. (1998) Comparative feeding behaviour and niche organisation in a Mediterranean duck community. Can. J. Zool. 76: 500-507.

Greenwood, R. J., Sargeant, A. B., Johnson, D. H., Cowardin, L. M. and Shaffer, T. L. (1995) Factors associated with duck nest success in the Prairie Pothole Region of Canada. Wildl. Monogr. 128: 1-57.

Greenwood, R. J., Pietruszewski, D. G. and Crawford, R. D. (1998) Effects of food supplementation on depredation of duck nests in upland habitat. Wildl. Soc. Bull. 26: 219-226. 
Guyn, K. L. and Clark, R. G. (1997) Cover characteristics and success of natural and artificial duck nests. J. Field. Ornithol. 68: 33-41.

Hammond, M. C. and Forward, W. R. (1956) Experiments on causes of duck nest predation. J. Wildl. Manage. 20: 243-247.

Johnson, D. H., Sargeant, A. B. and Greenwood, R. J. (1989) Importance of individual species of predators on nesting success of ducks in the Canadian Prairie Pothole Region. Can. J. Zool. 67: 291-297.

Juhász, M. (1997) Actual vegetation map of Barcs Nature Reserve, 1985 (Hungary). Pp. 323-328 in Proceedings of "Research, Conservation, Management" Conference, Aggtelek, Hungary, 1-5 May 1996.

Juhász, M., Szerdahelyi, T. and Szollát, G. (1985) Natural conservation troubles in the Preservation Area of Barcs (Hungary) - on a stand of botanists' experiences. Studia Pannonica (A) Series Historico-Naturalis 5: 241-243. (In Hungarian with English summary.)

Kárpáti, L. (1979) Die Vogelwelt des Urwacholderbestandes von Barcs. Somogyi Almanach 30: 1-52. (In Hungarian with German summary.)

Klett, A. T., Shaffer, T. L. and Johnson, D. H. (1988) Duck nest success in Prairie Pothole Region. J. Wildl. Manage. 52: 431-440.

Krasowski, T. P. and Nudds, T. D. (1986) Microhabitat structure of nest sites and nesting success of diving ducks. J. Wildl. Manage. 50: 203-208.

Krivenko, V. G., Vinogradov, V. G., Green, A. and Perennou, C. (1994) Ferruginous Duck Aythya nyroca. Pp. 130-131 in Tucker, G. M. and Heath, M. F., eds. Birds in Europe: their conservation status. Cambridge, U.K.: BirdLife International (Conservation Series 3 ).

MacIvor, L. H., Melvin, S. M. and Griffin, C. R. (1990) Effects of research activity on piping plover nest predation. J. Wildl. Manage. 54: 443-447.

Magyar, G., Hadarics, T., Waliczky, Z., Schmidt, A., Nagy, T. and Bankovics, A. (1998) Nomenclator avium Hungariae. Budapest, Szeged: Madártani Intézet-MME-Winter Fair.

Major, R. E. and Kendal, C. E. (1996) The contribution of artificial nest experiments to understanding avian reproductive success: a review of methods and conclusions. Ibis 138 : 298-307.

Marián, M. and Puskás, L. (1985) Avifauna of the Barcs Juniper Woodland, Hungary. Studia Pannonica (A) Series Historico-Naturalis 5: 207-232. (In Hungarian with German summary.)

Martin, T. E. (1995) Avian life history evolution in relation to nest sites, nest predation and food. Ecol. Monogr. 65: 101-127.

Matthews, A., Dickman, C. R. and Major, R. E. (1999) The influence of fragment size and edge on nest predation in urban bushland. Ecography 22: 349-356.

Maxson, S. J. and Riggs, M. R. (1996) Habitat use and nest success of overwater nesting ducks in westcentral Minnesota. J. Wildl. Manage. 60: 108-119.

Mayfield, H. (1975) Suggestions for calculating nest success. Wilson Bull. 87: 456-466.

Olson, R. and Rohwer, F. C. (1998) Effects of human disturbance on success of artificial duck nests. J. Wildl. Manage. 62: 1142-1146.

Opermanis, O., Mednis, A. and Bauga, I. (2001) Duck nests and predators: interaction, specialisation and possible management. Wildl. Biol. 7: 87-96.

Paton, W. C. (1994) The effect of edge on avian nesting success: how strong is the evidence? Conserv. Biol. 8: 17-26.

Petkov, N., Hughes, B. and Gallo-Orsi, U., eds. (2003) Ferruginous Duck: from research to conservation. Sofia: BirdLife International-BSPB-TWSG (Conservation Series 6).

Robinson, J. A. and Hughes, B. (2003) The global status and distribution of the Ferruginous Duck. Pp. 8-17 in Petkov, N., Hughes, B. and Gallo-Orsi, U., eds. Ferruginous Duck: from research to conservation. Sofia: BirdLife International-BSPB-TWSG (Conservation Series 6).

Sargeant, A. B. and Arnold, P. M. (1984) Predator management for ducks on waterfowl production areas in the northern plains. Vertebr. Pest Conf. 11: 161-167. 
Söderström, B., Pärt, T. and Rydén, J. (1998) Different nest predator faunas and nest predation risk on ground and shrub nests at forest ecotones: an experiment and a review. Oecologia 117: 108-118.

Vacca, M. M. and Handel, C. M. (1988) Factors influencing predation associated with visits to artificial goose nests. J. Field. Ornithol. 59: 215-223.

Weller, M. W. (1979) Density and habitat relationships of Blue-Winged Teal nesting in northwestern Iowa. J. Wildl. Manage. 43: 367-374.

Wieloch, M. (2002) The status of the Ferruginous Duck in Poland. Pp. 28-31 in Petkov, N., Hughes, B. and Gallo-Orsi, U., eds. Ferruginous Duck: from research to conservation. Sofia: BirdLife International-BSPB-TWSG (Conservation Series 6).

Yahner, R. H. and Wright, A. L. (1985) Depredation on artificial ground nests: effects of edge and plot age. J. Wildl. Manage. 49: 508-513.

Zar, J. H. (1999) Biostatistical Analysis. Fourth edition. London: Prentice Hall International.

JENŐ J. PURGER* and LÍDIA A. MÉSZÁROS

Department of Animal Ecology, Institute of Biology, Faculty of Sciences, University of Pécs, Ifjúság útja 6. H-7624 Pécs, Hungary.

*Author for correspondence; E-mail: purger@ttk.pte.hu

Received 7 May 2004; revision accepted 20 December 2005 